\title{
Electrochemical Oxidation of Oxalic Acid in the Presence of Halides at Boron Doped Diamond Electrode
}

\author{
C. A. Martínez-Huitle, ${ }^{*, a}$ S. Ferro, ${ }^{b}$ S. Reyna, ${ }^{c}$ M. Cerro-López, ${ }^{c}$ A. De Battisti ${ }^{b}$ and M.A. Quiroz ${ }^{*}, c$ \\ ${ }^{a}$ Dept. Analytical Chemistry, University of Milan, via Celoria 2-20133 Milán, Italy \\ ${ }^{b}$ Dept. of Chemistry, Lab. Electrochemistry, University of Ferrara, Via L. Borsari, \\ 46-4100 Ferrara, Italy
}

'Dept. Química y Biología, Lab. de Electroquímica, Universidad de las Américas-Puebla, Sta. Catarina Mártir, Cholula 72820 Puebla, México

\begin{abstract}
O objetivo deste trabalho é discutir a oxidação eletroquímica do ácido oxálico (AO), analisando a influência do $\mathrm{NaCl}$ e $\mathrm{NaBr}$. Experimentos foram realizados em eletrodos de diamante dopados com boro (DDB), em meio alcalino. Eletrodos DDB têm uma baixa adsortividade superficial, portanto sua grande estabilidade frente à oxidação permite que a reação ocorra com reagentes e intermediários não adsorvidos. O processo é significativamente acelerado pela presença de sal de halogênio na solução; curiosamente, o processo mediado não depende da densidade de corrente aplicada. Com base nos resultados, o brometo foi selecionado como um mediador apropriado durante a oxidação de $\mathrm{AO}$ em DDB. $\mathrm{Br}^{-}$age primeiramente no volume da solução, com a formação de oxidantes fortes, enquanto a ação do $\mathrm{Cl}^{-}$mostrou melhoras mais baixas na oxidação do AO em BDD, com relação aos resultados relatados usando eletrodo de Pt. Finalmente, os parâmetros de eficiência de remoção e consumo de energia para a incineração eletroquímica de AO foram calculados.
\end{abstract}

Aim of this work is to discuss the electrochemical oxidation of oxalic acid (OA), analyzing the influence of $\mathrm{NaCl}$ and $\mathrm{NaBr}$. Experiments were carried out at boron-doped diamond (BDD) electrodes, in alkaline media. BDD electrodes have a poor superficial adsorptivity so their great stability toward oxidation allows the reaction to take place with reactants and intermediates in a non-adsorbed state. The process is significantly accelerated by the presence of a halogen salt in solution; interestingly, the mediated process does not depend on applied current density. Based on the results, bromide was selected as a suitable mediator during OA oxidation at $\mathrm{BDD}$. $\mathrm{Br}^{-}$ primarily acts in the volume of the solution, with the formation of strong oxidants; while $\mathrm{Cl}^{-}$action has shown lower improvements in the OA oxidation rate at BDD respect to the results reported using Pt electrode. Finally, the parameters of removal efficiency and energy consumption for the electrochemical incineration of OA were calculated.

Keywords: indirect oxidation, mediators, oxalic acid, halides, boron doped diamond

\section{Introduction}

Electrochemical treatment is one of the methods used for the removal of organic and inorganic impurities from water and waste water. Consequently, several research groups are attempting to use electrochemical methods as an effective method for detoxification of wastewaters containing biorefractory pollutants. ${ }^{1-8}$ The literature has shown that, the electrochemical oxidation represents an alternative in wastewater treatment, ${ }^{6-9}$ and this process

*e-mail: Carlos.Martinez@unimi.it; marcoa.quiroz@udlap.mx can be subdivided in two main categories: "Direct" and "Indirect" as schematized in Table 1.

According to information in Table 1, while the electron transfer takes place between electrodes and decomposable species in direct electrochemical oxidation, indirect oxidation mainly uses electrochemically oxidized species as mediators for the destruction of organic compounds. Reactive and high-valent metal ions which are electrochemically generated from stable and low valent state were also utilized to degrade organic pollutants. Various redox couples such as $\mathrm{Ag}^{+} / \mathrm{Ag}^{2+}, \mathrm{Co}^{2+} / \mathrm{Co}^{3+}$, $\mathrm{Fe}^{2+} / \mathrm{Fe}^{3+}$, and $\mathrm{Ce}^{3+} / \mathrm{Ce}^{4+}$ were examined as mediators. ${ }^{10-15}$ 
Table 1. Principal characteristics of the electrochemical processes: Direct and Indirect electrochemical oxidation

\begin{tabular}{|c|c|c|}
\hline & Direct oxidation & Indirect oxidation, also called mediated electrochemical oxidation \\
\hline Objective & $\begin{array}{l}\text { The complete oxidation of organics to } \mathrm{CO}_{2} \text { or the } \\
\text { conversion of the toxic organics to biocompatible } \\
\text { compounds }\end{array}$ & Complete pollutants conversion to $\mathrm{CO}_{2}, \mathrm{H}_{2} \mathrm{O}$ and other inorganic components \\
\hline Method & $\begin{array}{l}\text { Water is passed through cathodic and anodic } \\
\text { compartments of one or more electrochemical } \\
\text { cells with specific features. }\end{array}$ & $\begin{array}{l}\text { Anodically formed oxidants }\left(\mathrm{Cl}_{2}, \mathrm{HClO}, \mathrm{H}_{2} \mathrm{O}_{2}, \mathrm{O}_{3} \text {, Fenton's reagent, }\right. \\
\left.\text { peroxodisulphate... but also } \mathrm{Ag}^{\mathrm{II} / \mathrm{I}}, \mathrm{Ce}^{\mathrm{IV} / \mathrm{III}}\right) \text { react with organic substrates }\end{array}$ \\
\hline Factors & $\begin{array}{l}\text { Current, } \mathrm{pH} \text {, temperature, anodic material, } \\
\text { Faradaic processes (cathodic reduction, anodic } \\
\text { oxidation) }\end{array}$ & Current, pH "shock", Faradaic processes, nature of the oxidants \\
\hline Results & Elimination of organic pollutants from water & $\begin{array}{l}\text { Elimination of organic pollutants from water, good current efficiencies, } \\
\text { no formation of chlorinated products (in Cl-mediated processes) }\end{array}$ \\
\hline
\end{tabular}

On other hand, for indirect electrooxidation, destruction of organic compounds by anodically generated chlorine and hypochlorite is well known. A particularly interesting case is that of active-chlorine mediation, which has been reported in several papers. ${ }^{16-23}$ The interest for this path to electrochemical incineration is due to two reasons: (i) the ubiquitous presence of chloride ions in a number of effluents and also of natural waters, which makes the involvement of active chlorine in anodic processes in these media, inevitable; (ii) the chemistry and electrochemistry of chlorine higher oxidation states at $\mathrm{pH}$ not far from neutrality, makes its use as incineration mediator of some practical interest. ${ }^{1}$

The complexity of active-chlorine reactivity in the presence of organics deserves further thorough insight. Within this frame, the electrochemical approach may supply a considerable improvement, just through a more careful control of process variables.

Ferro and co-workers ${ }^{20}$ reported that at different $\mathrm{pH}$ values in the alkaline region, a complex substrate like glucose can be incinerated within a wide anodic current density range. These experimental data were accounted by the assumption that the main part of the incineration process is a surface reaction, based on adsorbed oxychloro radicals. The role played by the anodic shift of the oxygen evolution, caused by $\mathrm{Cl}^{-}$ions in solution, has been considered. In fact, this aspect has been discussed in a few papers, ${ }^{1,24,25}$ mainly in relation with the electrosynthesis of strong oxidants.

It is clear from the literature, that most of the works attempted to degrade complex substrates at high concentration using anodic materials and then conducted experiments at alkali or acidic conditions. As a result, if the electrochemical technology has to become practically applied, low concentration halogen salts must be considered to increase the elimination rate.

As a further development of the research carried out in the previous studies, ${ }^{1,19,20}$ in the present work it has been considered opportune to extend the research to the anodic oxidation of oxalic acid (OA), in the presence of different halides on the BDD anode. OA has been considered an interesting substrate, ${ }^{26,27}$ because of its insufficient reactivity toward anodic oxidation and as a possible by-product of incomplete mineralization of more complex organic frames. Therefore, the electrochemistry of OA at several electrodes materials has been studied. ${ }^{1,26,27,32}$ Most of the investigations have been carried out using platinum, gold, $\mathrm{PbO}_{2}, \mathrm{IrO}_{2}$ and diamond electrodes. ${ }^{1,26-29,32}$

On the other hand, OA has many diverse manufacturing and industrial uses including use in fabric printing and dyeing; bleaching straw hats; removing paint, varnish, rust or ink stains; and cleaning wood. After these industrial applications this compound is discharged in the water effluents. ${ }^{30} \mathrm{OA}$ also is the final intermediate of degradation of many pollutants as phenol, dyes, oils, etc. ${ }^{31}$

$\mathrm{OA}$ is corrosive to the eyes and skin, and has been placed in Toxicity Category I (indicating the highest degree of toxicity) for acute eye and skin irritation effects. It also is highly irritating and damaging to the respiratory system if inhaled. Acute exposure also causes stomach irritation, lowered calcium levels, effects to the nervous system and kidney damage in humans. ${ }^{30}$ The results are described and discussed in the light of the existing literature.

\section{Experimental}

Bulk electrolyses were carried out in a single-body, thermostated Pyrex glass cell of $250 \mathrm{~mL}$; the anode was a BDD plate, with a geometrical area of $15 \mathrm{~cm}^{2}$, and the test solution volume was $200 \mathrm{~mL}$. A Zr plate was used as the counter electrode when the BDD anode was investigated. Thin, highly boron-doped diamond electrodes (BDD) films were synthesized by Adamant Technologies (Neuchatel, Switzerland). The diamond films have a thickness of $1 \mu \mathrm{m}$ $( \pm 10 \%)$ and a resistivity of $15 \mathrm{~m} \Omega \mathrm{cm}( \pm 30 \%)$, consistent with a boron concentration between 3500 and 5000 ppm. 
Experiments were performed at room temperature ( $c a$. $25^{\circ} \mathrm{C}$ ), investigating the role of applied current density $\left(j_{a p p l}\right)$ and mediators; the $j_{\text {appl }}$ range was established at 300 and $600 \mathrm{~A} \mathrm{~m}^{-2}$. Solutions were vigorously stirred, using a magnetic stirrer. The stirring rate was kept almost constant $(350 \pm 10 \mathrm{rpm})$. In this condition, the estimate mass transfer coefficient in the cell, determined using the ferri/ ferrocyanide couple, was $2 \times 10^{-5} \mathrm{~m} \mathrm{~s}^{-1}$.

Cyclic voltammetries $(\mathrm{CV})$ were performed at room temperature in solutions stirred by bubbling nitrogen and at a scan rate of $100 \mathrm{mV} \mathrm{s}^{-1}$; the chosen range potential was cycled using a step potential of $2 \mathrm{mV}$ and repeating the measurement at least five times or until these were reproducible signals; in every case, the last cycle was recorded. The nominal BDD area of the electrode was $0.78 \mathrm{~cm}^{2}$ (a disk with a diameter of $1 \mathrm{~cm}$ ) and a small $\mathrm{Pt}$ wire was used, with the same real surface area.

The current density for the electrolysis was kept at the desired level with a Tacussel model PJT24-1 (24V-1A) potentiostat-galvanostat. Potential values were referred to a saturated calomel electrode (SCE). Fresh $0.1 \mathrm{~mol}$ $\mathrm{dm}^{-3}$ solutions of oxalic acid (Fluka, dihydrate salt) were prepared upon use in $0.25 \mathrm{~mol} \mathrm{dm}^{-3} \mathrm{NaOH}$ (Fluka) and 0.5 mol dm ${ }^{-3} \mathrm{Na}_{2} \mathrm{SO}_{4}$ (Fluka), using distilled water. $\mathrm{NaCl}$ and $\mathrm{NaBr}$ (Fluka) were used as received, without any further purification. During the electrolysis, the oxalic acid residual content was determined by means of a conventional titration method with $\mathrm{KMnO}_{4} \cdot{ }^{32}$

The efficiency parameters for the anodic oxidation have been calculated, using the equations described in Table 2 . In the case of the TCE, the COD values were considered at the initial and final times for a global determination of the total efficiency during the process. The energy consumption for the removal of one $\mathrm{kg}$ of COD was also calculated and expressed in $\mathrm{kW} \mathrm{h}^{-1}$. In all cases, COD values were determined based on the residual concentration of $\mathrm{OA}$ in solution.

In addition, as a first step, we have characterized typical BDD surface topologies by atomic force microscopy (AFM); a Nanoscope IIIa Scanning Probe microscope controller connected with a nanoscope multimode SPM, both from Digital Instruments were adopted for AFM analysis.

\section{Results and Discussion}

\section{Morphological characterization of the diamond films}

Figure 1 shows AFM image of polycrystalline films deposited on $p$-Si. This figure shows that the boron doped diamond layer is continuous and consists of microcrystals randomly arranged and it is similar to those already reported in the literature. ${ }^{33-35}$

\section{Electrochemical characterization}

Figure 2 shows the cyclic voltammograms for acidic and alkaline media on diamond electrodes. The cyclic voltammetric curves for the diamond electrode obtained after purging with nitrogen gas is featureless, and the background current is very low (less than $1<\mathrm{A}$ ) in both

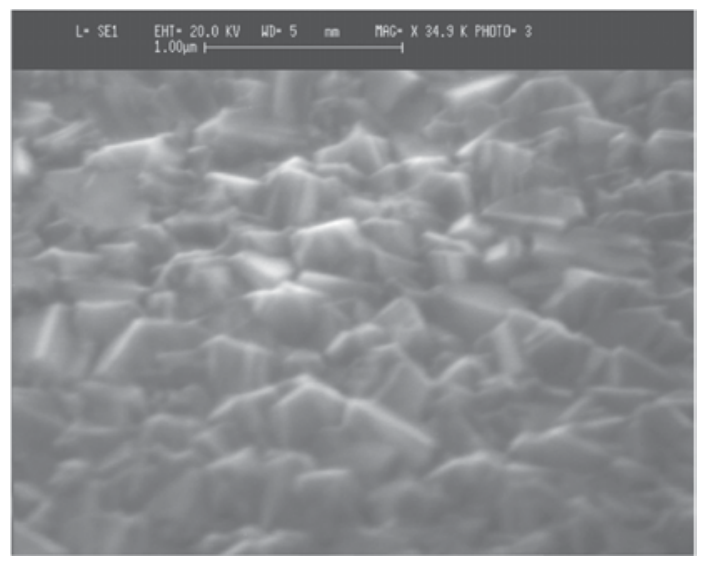

Figure 1. BDD images carried out by the AFM technique.
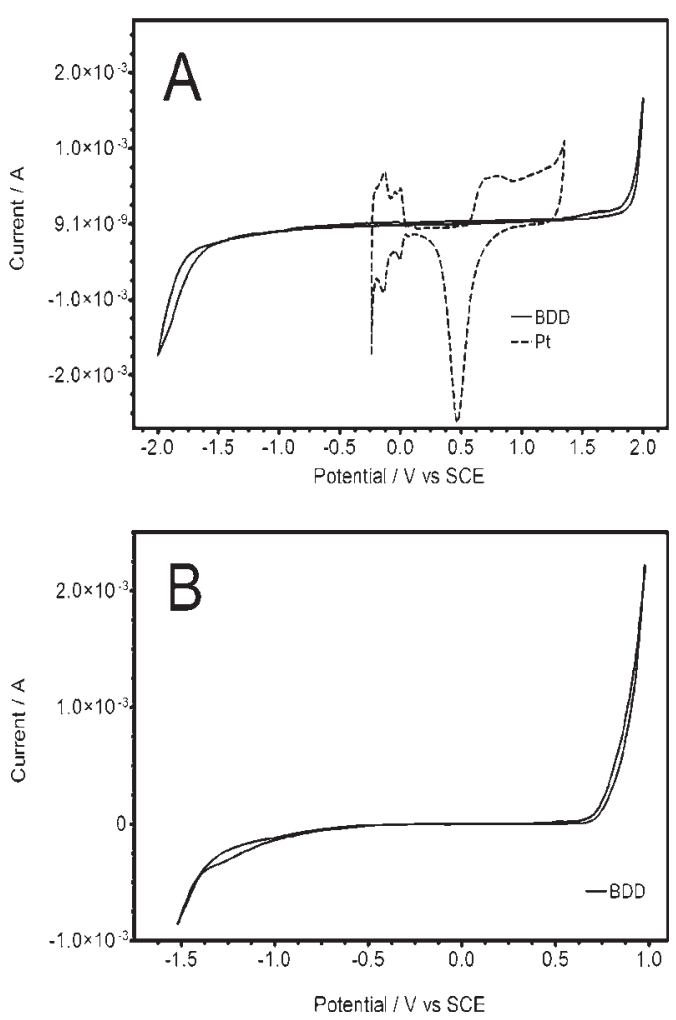

Figure 2. A) $\mathrm{CV}$ curves for the BDD and Pt electrodes, in acidic media $\left(0.5 \mathrm{~mol} \mathrm{dm}^{-3} \mathrm{H}_{2} \mathrm{SO}_{4}\right)$ and $\left.\mathrm{B}\right) \mathrm{CV}$ curves for the BDD electrode, in alkaline media $\left(0.25 \mathrm{~mol} \mathrm{dm}^{-3} \mathrm{NaOH}+0.5 \mathrm{~mol} \mathrm{dm}^{-3} \mathrm{Na}_{2} \mathrm{SO}_{4}\right)$. BDD area of the electrode was $0.78 \mathrm{~cm}^{2}$ and a small Pt wire was used, with the same real surface area. Scan rate: $100 \mathrm{mV} \mathrm{s}^{-1}$. 
cases. In the acidic media the oxygen evolution peak appear about $+2.0 \mathrm{~V} v s$. SCE (curve A). On the other hand, the curve B exhibited a broad oxidation peak at $c a .+0.9 \mathrm{~V} v s$. SCE. Thus it can be assumed that this peak is due to the water decomposition. These results are in agreement with Yano et al. ${ }^{36}$ Finally, a comparison between Pt and BDD electrode was made in the Figure 2A, where BDD electrode exhibits a most important characteristic: a potential window $4 \mathrm{~V}$ wide.

\section{Anodic oxidation of oxalic acid}

In a previous paper, ${ }^{32}$ the electrochemical incineration of OA was studied, in acidic media using different electrode materials. At the Figure $8,{ }^{32}$ the results obtained at BDD electrodes showed that, under comparable conditions, the incineration rate is lower than at other anodic materials, and is only moderately enhanced by an increase of the solution temperature. This experimental evidence supports the idea that the interaction between the organic substrate and the electrode surface is likely to be a condition for the fast incineration to take place. A weaker interaction, possibly taking place between $\mathrm{OA}$ and BDD, is apparently not enough to promote a fast oxidation, although favouring in principle a possible hydroxyl radical electrosorption. ${ }^{32}$

Nevertheless, the better results were obtained with a Pt electrode, ${ }^{32}$ but its rate decreased to almost zero below an OA concentration limit that was higher, as the anodic $j_{a p p l}$ value increased. This impediment was overcame by changing the medium from acidic to alkaline, ${ }^{1}$ allows for a complete elimination of OA also at the highest current density values. In addition, several experiments were carried out at a Pt electrode in alkaline media, where a fast electro-oxidation was found to proceed in the presence of a halogen salt. ${ }^{1}$ The rate of the electrochemical incineration is significantly increased, following the order $\mathrm{F}^{-}>\mathrm{Br}^{-}>\mathrm{Cl}^{-}$, and the "mediated" process proved to be practically independent of the applied current density. According to these results and to further enrich the research, the investigations were extended to BDD electrode in presence of halides. The case of BDD electrodes is interesting, as they do not provide an active site for the adsorption of reactants, and have no electrocatalytic activity for the direct oxidation of some organic compounds such as aliphatic alcohols (methanol, ethanol, $i$-propanol, tert-butanol) or carboxylic acids (formic acid, oxalic acid, maleic acid). ${ }^{26,37}$ In fact, on BDD, which is well known to have weak adsorption properties, hydroxyl radicals are very weakly adsorbed and consequently they are more reactive towards organic oxidation (representing a sort of "reaction cage" for the process) than hydroxyl radicals electrogenerated on other anodic materials, where they are more strongly adsorbed and consequently less reactive. Therefore, the BDD anode is commonly considered a "non active" electrode respect to Pt that is classified as "active".

Figure 3 shows the electrochemical oxidation of OA at $\mathrm{BDD}$ electrode under acidic and alkaline conditions, $\mathrm{H}_{2} \mathrm{SO}_{4}$ and $\mathrm{NaOH} / \mathrm{Na}_{2} \mathrm{SO}_{4}$, respectively. It indicates that the curves have some changes at existing experimental conditions. At alkaline medium, OA oxidation is faster at the beginning of the process respect to acidic conditions and limited in the final stages by the oxygen evolution reaction. This effect may be due to the extensive oxidation and/or chemical modification (under alkaline conditions)

Table 2. Equations of efficiency for the electrochemical oxidation ${ }^{1,18,40}$

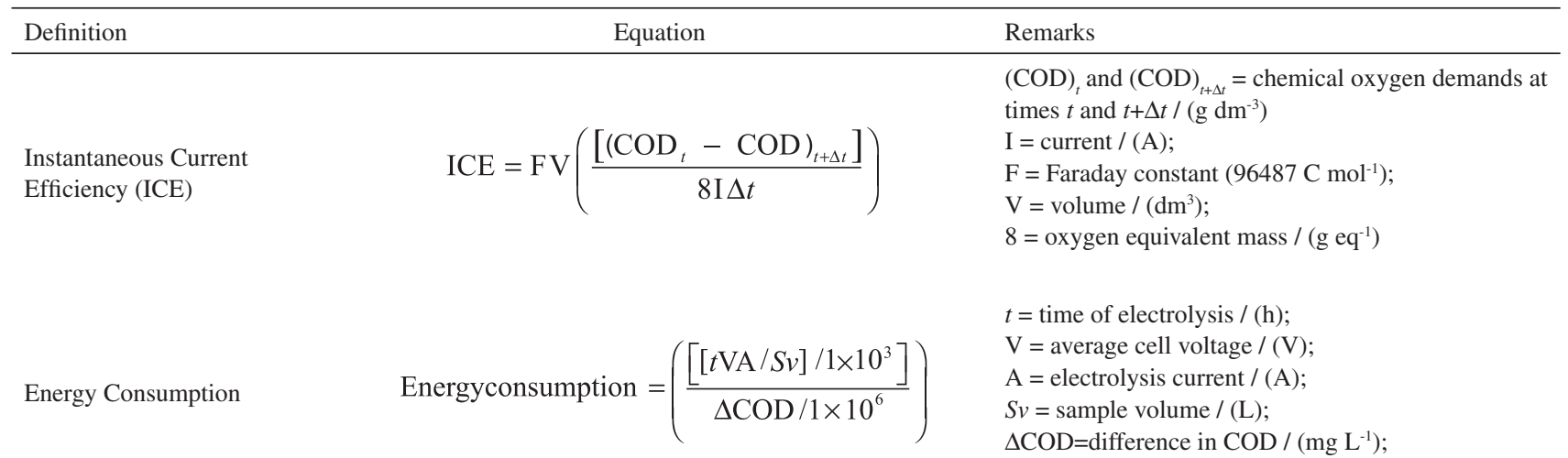

Total Current Efficiency (TCE)

$$
\mathrm{TCE}=\mathrm{FV}\left(\frac{\left[(\mathrm{COD})_{i}-(\mathrm{COD})_{f}\right]}{8 \mathrm{I} \Delta t}\right)
$$

The variables have the same meaning described above for the ICE. 


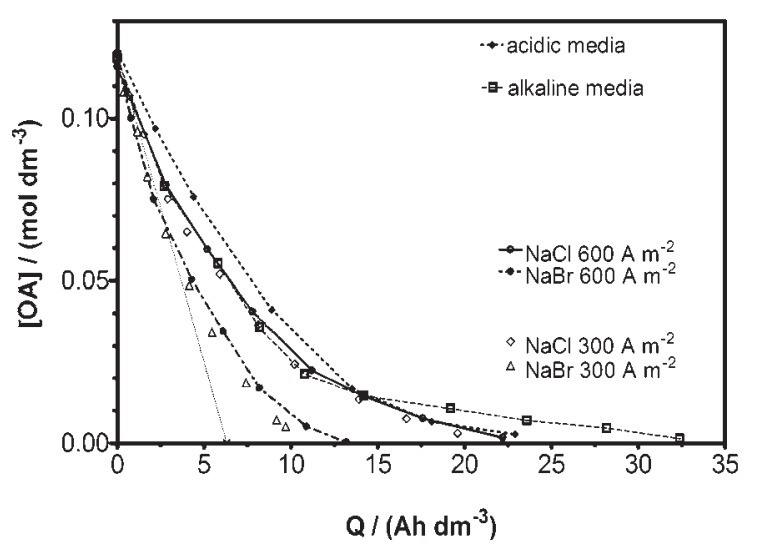

Figure 3. Decrease of the OA content in solution, at the BDD electrode, as a function of charge, in acidic $\left(0.5 \mathrm{~mol} \mathrm{dm}^{-3} \mathrm{H}_{2} \mathrm{SO}_{4}\right)$ and alkaline $(0.25$ $\left.\mathrm{mol} \mathrm{dm}{ }^{-3} \mathrm{NaOH}+0.5 \mathrm{~mol} \mathrm{dm}{ }^{-3} \mathrm{Na}_{2} \mathrm{SO}_{4}\right)$ media. $j_{\text {appl }}=600 \mathrm{~A} \mathrm{~m}^{-2}$. Effects of $\mathrm{NaCl}$ and $\mathrm{NaBr}\left(5 \mathrm{~g} \mathrm{dm}^{-3}\right)$ at different applied current densities.

of the electrode surface, which suggests a change in the surface properties. Duo et al. ${ }^{38}$ reported that the chemical and electrochemical properties of diamond electrodes were found to be strongly influenced by the surface treatment. A relatively mild polarization process was sufficient to transform the surface from hydrophobic (BDD as-grown) to hydrophilic (BDD mildly oxidized) without changes in the crystal shape and size. On the other hand, Wadhawan et al. ${ }^{39}$ reported that at high potentials and current densities the BDD electrode can become increasingly hydrophilic and can increase the extent of its adsorptive properties. This behaviour suggests that OA oxidation at alkaline conditions is due to the increase of the electroactivity of the BDD anode toward the OA molecules due to surface oxidation, increasing the oxidative efficiencies respect to acidic conditions.

To investigate the role of halides, the OA anodic oxidation experiments were carried out in the presence of $5 \mathrm{~g} \mathrm{dm}^{-3}$ of halides in the solution and performed under galvanostatic conditions at 300 and $600 \mathrm{~A} \mathrm{~m}^{-2}$. As shown in Figure 3, the electrochemical oxidation of OA at the BDD electrode is significantly accelerated by the presence of a halogen salt in solution; interestingly, the mediated process does not depend on applied current density. Analogous results were obtained at other anodic materials by Bonfatti et al. ${ }^{19}$ Martinez-Huitle et al. ${ }^{1}$ and Panizza and Cerisola. ${ }^{21}$ However, on the basis of data in Figure 3, $\mathrm{NaBr}$ seems to be better mediator than $\mathrm{NaCl}$, allowing higher current efficiencies as reported in Table 3.

According to measurements reported previously ${ }^{1}$ and results obtained by other authors ${ }^{19,20,40}$ the electrochemical mediation seems to be the consequence of some specific roles played by the considered halogen salt; the organic incineration is accelerated by halide ions in the series: $\mathrm{Br}^{-}>\mathrm{Cl}^{-}$. Although an increase in faradaic efficiency of organic substrate incineration is a common feature of $\mathrm{Br}^{-}$, with respect to the $\mathrm{Cl}^{-}$-mediated situation, the mechanism behind this effect is likely to be very different. In the case of $\mathrm{Br}^{-}$, the main factor seems to be the electrogeneration of strong oxidants (Br-based oxy-anions), which mainly react through bulk reactions as reported by Martinez-Huitle et al. ${ }^{1}$ Finally, the $\mathrm{Cl}^{-}$effect can be a hybrid of the above two cases, with the possible electrogeneration of strong oxidants, ${ }^{20}$ and hydroxyl radicals by water decomposition.

According to results obtained by Förster et al. ${ }^{41}$ few comparative investigations were performed about hypochlorite formation on platinum and diamond electrodes; the hypochlorite formation yield on diamond film electrodes was found higher than on Pt electrodes. In this way, it is also important remark that the equilibrium between the different forms of active chlorine in the electrolysis solution depends on the $\mathrm{pH}$, temperature and concentration. ${ }^{41,42}$ As can be observed in Figure 1 in Reference 41 , the $\mathrm{pH}$ range where a high concentration of hypochlorite was observed ranged from 7.74 to 11.5. Therefore, during the OA oxidation at alkaline media $(\mathrm{pH} \approx 10.3)$ the production and participation of hypochlorite can be considered. However, the evidence obtained by Ferro et $a l .{ }^{42}$ clearly shows that diamond electrodes are more efficient in the production of "active chlorine" (chlorine, hypochlorous acid and hypochlorite) at lower $\mathrm{pH}$ values. For this reason, in the alkaline media case, the "active chlorine production" can be considered in competition with an important parasitic reaction such as oxygen evolution, where it limits the electrogeneration of strong oxidants at BDD surface. Therefore, OA oxidation in presence of $\mathrm{NaCl}$ is faster in the beginning of the process (low active chlorine species production) and limited in the final stages by oxygen evolution reaction.

Table 3. Parameters of efficiency for the electrochemical oxidation of OA at BDD electrode. Energy consumption (kWh $\mathrm{kg}^{-1}$ of COD), calculated for a $90 \%$ elimination of the carboxylic acid content in the solution. In all cases, COD values were determined based on the residual concentration of OA in solution

\begin{tabular}{lccccc}
\hline & Alkaline media & Acidic media & $300 \mathrm{~A} \mathrm{~m}^{-2}, \mathrm{NaCl}$ & $600 \mathrm{~A} \mathrm{~m}^{-2}, \mathrm{NaCl}$ & $300 \mathrm{~A} \mathrm{~m}{ }^{-2}, \mathrm{NaBr}^{6} 600 \mathrm{~A} \mathrm{~m}{ }^{-2}, \mathrm{NaBr}^{2}$ \\
\hline Energy consumption & 42.9 & 39.7 & 28.9 & 39.4 & 14.6 \\
\% ICE & 79.1 & 58.8 & 98.0 & 70.0 & 100.0 \\
\% TCE & 20.9 & 29.0 & 34.8 & 29.23 & 100.0 \\
\hline
\end{tabular}




\section{Influence of applied current density}

As can be observed in Figure 3, under the considered experimental conditions, the "mediated" process is practically independent of the applied current density. This observation is in agreement with the data obtained by other authors. ${ }^{19-21}$ Though the current density does not have a significant influence on organic substrate elimination, the energy consumption for COD removal increases with the current density, which, in turn, is related to cell voltage. Considering a $90 \%$ COD removal, the requested energy has been calculated from equation in Table 2 and data are collected in Table 3. For example, in the $\mathrm{Cl}^{-}$-mediated OA oxidation, the energy consumption increased from 28.9 to $39.4 \mathrm{kWh}$ per $\mathrm{Kg}$ of COD as the current density was increased from 300 to $600 \mathrm{~A} \mathrm{~m}^{-2}$.

\section{Conclusions}

In this work, the electrochemical oxidation of OA at BDD electrode has been investigated under different experimental conditions. Bulk electrolyses have shown that in the absence of halide ions, only a slow OA concentrarion depletion was obtained. On the other hand, in the presence of $\mathrm{NaCl}$, OA was completely oxidized by mediation of the electrogenerated active chlorine in the beginning of the process. Nevertheless, this process showed lower improvements respect the absence of halides in solution. Interestingly, the best results in terms of OA concentration removal rate and current efficiency were obtained when electrolyses were carried out with $\mathrm{NaBr}$. It was also found that $\mathrm{OA}$ depletion was independent of the applied current density. $\mathrm{Br}^{-}$primarily acts in the volume of the solution, with the formation of strong oxidants. The competition between the oxygen evolution reaction and the organic electro-oxidation is additionally complicated by the role of each specific halide. For this reason, the next step in our investigations will be determine a detailed analysis of oxidants species evolution $\left(\mathrm{HOBr}, \mathrm{HBrO}_{2}, \mathrm{BrO}_{2}\right.$, $\mathrm{BrO}_{3}^{-}, \mathrm{Br}^{-}$and/or $\mathrm{Br}_{2}$ ) during the oxidation of $\mathrm{OA}$ in presence of $\mathrm{NaBr}$ at $\mathrm{BDD}$ electrode.

\section{Acknowledgments}

This research was supported in part by a grant-in-aid from the University of the Americas, Puebla (UDLAP/ DIP) and by a grant from the National Council of Science and Technology of México. The authors thank Adamant Technologies (Neuchâtel, Switzerland), for providing the BDD samples. We thank Prof. Miguel Angel Mendez-Rojas (UDLAP-México) for helpful discussion and comments.

\section{References}

1. Martínez-Huitle, C. A.; Ferro, S.; De Battisti, A.; Electrochem. Solid-State Lett. 2005, 8, D35.

2. Comninellis, Ch.; Pulgarin, C.; J. Appl. Electrochem. 1993, 23, 108.

3. Comninellis, Ch.; Electrochim. Acta 1994, 39, 1857.

4. Rajeshwar, K.; Ibañez, J. G.; Swain, G. M.; J. Appl. Electrochem. 1994, 24, 1077.

5. Rodgers, J. D.; Jedral, W.; Bunce, N. J.; Environ. Sci. Technol. 1999, 33, 1453.

6. Galla, U.; Kritzer, P.; Bringmann, J.; Schmieder, H.; Chem. Eng. Technol. 2000, 23, 3.

7. Steward, G.A.; US Pat. 5,756,874, 1998.

8. Nelson, N.; Platinum Metals Rev. 2002, 46, 18.

9. Jüttner, K.; Galla, U.; Schmieder, H.; Electrochim. Acta 2000, $45,2575$.

10. Chiang, L.-C.; Chang, J.-E.; Wen, T.-C.; Water Res. 1995, 29 , 671.

11. Farmer, J. C.; Wang, F. T.; Hawley-Fedder, R. A.; Lewis, P. R.; Summers, L. J.; Foiles, L.; J. Electrochem. Soc. 1992, 139, 654.

12. Bringmann, F.; Ebert, K.; Galla, U.; Schmieder, H.; J. Appl. Electrochem. 1995, 25, 846.

13. Dhooge, P. M.; Stilwell, D. E.; Park, S.-M.; J. Electrochem. Soc. 1982, 129, 1719.

14. Chung, Y. H.; Park, S.-M.; J. Appl. Electrochem. 2000, 30, 685.

15. Varela, J. A.; Oberg, S. G.; Neustedter, T. M.; Nelson, N.; Environ. Prog. 2001, 20, 261.

16. Mieluch, J.; Sadkowski, A.; Wild, J.; Zoltowski, P.; Prezm. Chem. 1975, 59, 513.

17. Boscolo Boscoletto, A.; Gottardi, F.; Milan, L.; Pannocchia, P.; Tartari, V.; Tavan, M.; Amadelli, R.; De Battisti, A.; Barbieri, A.; Patracchini, D.; Battaglin, G.; J. Appl. Electrochem. 1994, 24, 1852.

18. Comninellis, Ch.; Nerini, A.; J. Appl. Electrochem. 1995, 25, 23.

19. Bonfatti, F.; Ferro, S.; Lavezzo, F.; Malacarne, M.; Lodi, G.; De Battisti, A.; J. Electrochem. Soc. 2000, 147, 592.

20. Bonfatti, F.; De Battisti, A.; Ferro, S.; Lodi, G.; Osti, S.; Electrochim. Acta 2000, 46, 305.

21. Panizza, M.; Cerisola, G.; Electrochim. Acta 2003, 48, 1515.

22. Nikolaevsky, R.; Monosov, M.; Monosov, E.; Sharony, E.; Gurevich, D.; US Pat. 5,792,336, 1998.

23. Djeiranishvili, N.; Boutine, S.; Meerkop, G.E.; PCT Int. Appl. WO 9,827,013, 1998.

24. Hickling, A.; Wilson, W. H.; Nature 1949, 164, 673.

25. Balej, J.; Kaderavek, M.; Collect. Czech. Chem. Commun. 1981, 46, 2809.

26. Gandini, D.; Mahè, E.; Michaud, P. A.; Haenni, W.; Perret, A.; Comninellis, Ch.; J. Appl. Electrochem. 2000, 30, 1345. 
27. Ivandini, T. A.; Rao, T. A.; Fujishima, A.; Einaga, Y.; Anal. Chem. 2006, 78, 3467.

28. Berna, A.; Rodes, A.; Feliu, J. M.; J. Electroanal. Chem. 2004, $563,49$.

29. Pron'kin, S. N.; Petrii, O. A.; Tsirlina, G. A.; Schiffrin, D. J.; J. Electroanal. Chem. 2000, 480, 112.

30. EPA Reports, Office of Prevention; Pesticides and Toxic Substances, Dec. 1992, EPA-738-F-92-014. http://www.epa. gov/REDs/factsheets/4070fact.pdf.

31. Martínez-Huitle, C. A.; Ferro, S.; Chem. Soc. Rev. 2006, 35, 1324

32. Martínez-Huitle, C. A.; Ferro, S.; De Battisti, A.; Electrochim. Acta 2004, 49, 4027.

33. Ferreira, N. G.; Silva, L. L. G.; Corat, E. J.; Trava-Airoldi V. J.; Diamond Relat. Mater. 2002, 11, 1523.

34. Goeting, C. H.; Jones, F.; Foord, J. S.; Eklund, J. C.; Marken, F.; Compton, R. G.; Chalker, P. R.; Johnston. C.; J. Electroanal. Chem. 1998, 442, 207.

35. Ferro, S.; Ph.D. Thesis, University of Ferrara, Italy, 2002.
36. Yano, T.; Tryk, D. A.; Hashimoto, K.; Fujishima, A.; J. Electrochem. Soc. 1998, 145, 1870.

37. Gandini, D.; Michaud, P. A.; Duo, I.; Mahe, E.; Haenni, W.; Perret, A.; Comninellis, Ch.; New Diamond Front. Carbon Technol. 1999, 9, 303.

38. Duo, I. ; Levy-Clement, C. ; Fujishima, A .; Comninellis, Ch., J. Appl. Electrochem. 2004, 34, 935.

39. Wadhawan, J. D.; Del Campo, F. J.; Compton, R. G.; Foord, J. S.; Marken, F.; Bull, S. D.; Davies, S. G.; Walton, D. J.; Ryley, S.; J. Electroanal. Chem. 2001, 507, 135.

40. Rajkumar, D.; Kim, J. G.; Palanivelu, K.; Chem. Eng. Technol. 2005, 28, 98.

41. Förster, H. J.; Thiele, W.; Fassler, D.; Günther, K.; New Diamond Front. Carbon Technol. 2002, 12, 99.

42. Ferro, S.; De Battisti, A.; Duo, I.; Comninellis, Ch.; Haenni, W.; Perret, A.; J. Electrochem. Soc. 2000, 147, 2614.

Received: March 14, 2007 Published on the web: January 30, 2008 